The International Journal of Indian Psychology

ISSN 2348-5396 (e) | ISSN: 2349-3429 (p)

Volume 5, Issue 1, DIP: 18.01.125/20170501

DOI: $10.25215 / 0501.125$

http://www.ijip.in | October-December, 2017

Article

\title{
A Study of Educational Vision of Aurobindo Ghosh
}

\author{
Chanda Rani ${ }^{1 *}$
}

\section{ABSTRACT}

Philosopher Aurobindo Ghosh (1872-1950) was a great philosopher and educationalist. He can be viewed as a 20th-century renaissance person. He was born in Kolkata, India and completed his education from England. He built an Ashram which is famous as 'Aurobindo Ashram' all over the world. His philosophy of life was based on Vedas and Upanishads. He emphasized that Education should be in accordance with the need of our Modern life. The present paper highlights the Philosophical contribution of Aurobindo in education. This paper emphasis on educational concept, Aims of education, curriculum, methods of teaching, teacher-taught relationship, discipline and finally the implementation of Aurobindo's philosophy of education in the modern era.

Keywords: Aims of education, curriculum, teaching method, teacher-taught relations, discipline and implementation of Aurobindo philosophy in the modernand global era

Sri. Aurobindo Ghosh was not only a great philosopher but eminent idealistic philosopher, poet, guru, and educationalist also. According to Sri. Aurobindo, real education provides a free and creative environment to a child to grow him mentally, morally, aesthetically, and help to enhance his inner interest and creativity and finally leads to the development of his spiritual power. Aurobindo himself says, "The divine truth is greater than any religion or creed or scripture or idea or philosophy”. According to him, education should be dynamic so that it can be able to meet the needs of present complex life. Its central aim is building of the power of human mind and spirit.

\section{Aurobindo's Aims of education:}

Sri. Aurobindo was against the prevalent education system. He strongly believed that our education should be best suited to the need of modern life. Sri. Aurobindo himself writes "Education to be true must not be a machine made fabric but a true building or living evocation of the power of mind and spirit of human being”. According to Sri. Aurobindo, physical development, and purity of mind are the chief aims of education on which the spiritual development is built. The second aim of education is to train all the senses namely hearing, speaking, listening, touching, smelling, tasting. All senses can be fully trained when

\footnotetext{
${ }^{1}$ M.Com, M.ed, Double NET Qualified (COMMERCE + EDUCATION), JRF in Education, Ambala city, Haryana, India

*Responding Author

(C) 2017 Rani C; licensee IJIP. This is an Open Access Research distributed under the terms of the Creative Commons Attribution License (www.creativecommons.org/licenses/by/2.0), which permits unrestricted use, distribution, and reproduction in any Medium, provided the original work is properly cited.
} 


\section{A Study of Educational Vision of Aurobindo Ghosh}

the nerve, Chitta, and manas are pure. The third aim of education is development or enhancement of mental faculties namely memory, thinking, reasoning, imagination, and discrimination etc. Another important aim of education is the development of morality. Sri. Aurobindo has emphasized that without moral \& emotional development, mental development because harmful to human process. Development of conscience (Chitta, manas, intelligence, knowledge) and spirituality are essential for the all-round development of a child.

In the words of Sri. Aurobindo, "The chief aim of education should be to help the growing soul to draw out that in itself which is best and make it perfect for a noble use”.

\section{CURRICULUM}

Sri. Aurobindo prescribed free and creative environment for child \& stresses integrated curriculum which includes various activities, subjects and real-life experiences all in a unifying whole. He gave emphasis that curriculum should include all those subjects Which are according to need and interest of the child and promote his mental \& spiritual development. It should contain creativity of life and constructive capacities. He suggested various subjects according to the different level of a child. However, the curriculum should include basically those subjects which are very relevant to the society like mother tongue, English, history, social science, history, chemistry, physics, arithmetic, general science, literature, various foreign languages and various vocational subjects. Beside the above subjects, he also emphasized on yoga, arts, crafts, and music a part of regular curriculum.

\section{Methods of teaching:}

Sri. Aurobindo suggested various teaching method like observation, self-discovery, activity method, teaching with love and sympathy, learning by doing, discussion method, learning by self-experience, teaching-learning through mother tongue, learningwith co-operation during teaching-learning process.

\section{Teacher-taught relation:}

He believed that student is the Centre of the education process and every child has his own inherent interest and abilities, so it is the duty of a teacher to focus on the needs and demands of each and every student. Aurobindo himself written- "The Teacher is not an instructor or task-master, he is a helper and guider. His duty is to suggest and not to impose. He does not actually train the pupil's mind; he only shows him how to perfect the instruments of knowledge to him.”

Aurobindo has given three principles of true teaching. The teacher should follow these principles during the teaching-learning process:

1. The first principle of true teaching is that Nothing can be taught.

2. The second principle is that mind has to be consulted in its own growth.

3. The third principle of education is to work from near to far, from that from that which is to that which shall be. 


\section{A Study of Educational Vision of Aurobindo Ghosh}

\section{Discipline:}

Sri. Aurobindo believed in inner discipline. He was against the strict and harsh Discipline. He also believed that Children should be provided a free environment to express himself freely. Aurobindo propagated the concept of self-discipline.

\section{The implication of Aurobindo's philosophy in the modern and global era:}

Aurobindo Ghosh was an Indian philosopher, poet, yogi, guru, nationalist and great reformer. His theory best suited in the present context. Aurobindo's philosophy is based upon the theory of evolution. Sri Aurobindo aims at the evolution of individual, nation, and humanity through education.

The 20th century considered the birth of a new phenomenon in which the world is interconnected and dependent on each other termed as globalization. From the 20th century, various scientific discoveries have been seen in different areas like artificial satellites, enrichment of communication facilities genetic technology, space exploration, robotics and many other technologies. In spite of it, there are many horrible situations that the world is facing commonly. No permanent peace has been obtained so far. The mankind is living now with a great fear and worries. Global peace, values, and harmony cannot be achieved only through the science and technology. Due to the harshness of international problems, the tremendous idea of globalization now holds minimal concern for the majority of educators.

In this context, Sri Aurobindo's philosophical thoughts and principles of teaching are utmost important if a human being wants to live in peace and harmony. In the global era, his philosophy is very much relevant to achieve and maintain permanent peace in the world. It is very necessary to uplift the human being from the materiality to spirituality. Sri Aurobindo said,” peace is the first condition, without which nothing else can be stable”. A human being now engaged in searching the peace and happiness but "true happiness lies in the finding and maintenance of natural harmony of spirit, mind, and body” as Sri Aurobindo said. Sri Aurobindo has given the greater emphasis on yoga. He said, "The yoga we practice is not for ourselves alone, but for the Divine in the world, to effect a spiritual transformation and to bring down physical nature and life of humanity". He also said, "Yoga is a generic name for any discipline by which one attempts to pass out of the limits of one's ordinary mental consciousness into a greater spiritual consciousness. He also gave emphasis to national and international integration and value education, which promotes international Brotherhood and helps in character building worldwide.

\section{REFERENCES}

Aggarwal, J.C. (1985).Theory and principles of education. New Delhi: Vikas publishing House Pvt. Limited.

Chaube, S. (1993). Educational philosophy in India, Vikas publication House, New Delhi.

Debbarma, Sambhu. (2017).A study of educational thought's of Aurobindo Ghosh with relevance to the present educational context.Tripura: Department of education, India. 


\section{A Study of Educational Vision of Aurobindo Ghosh}

Devi, S. (1976).A critical study of the concept of creativity in philosophy with special reference to Bergsen whitehead and Sri Aurobindo. PH. D philosophy, Kurukshetra University.

Saxena, N.R. swaroop,\& Dutt, N.K. (2013).Philosophical \& sociological foundation of education. Vinay Rakheja publications, Meerut.

Sharma, R.A. (2015). Philosophical and sociological foundation of Education. Vinay Rakheja publications, Meerut.

How to cite this article: Rani C (2017). A Study of Educational Vision of Aurobindo Ghosh. International Journal of Indian Psychology, Vol. 5, (1), DIP: 18.01.125/20170501, DOI: $10.25215 / 0501.125$

(C) The International Journal of Indian Psychology, ISSN 2348-5396 (e) | ISSN: 2349-3429 (p) | 51 